\title{
Gene promoter hypermethylation in leukoplakia of the oral mucosa
}

This article was published in the following Dove Press journal:

Pathology and Laboratory Medicine International

6 July 2010

Number of times this article has been viewed

\author{
Mingli Liu' \\ Lei Feng ${ }^{2}$ \\ Ximing Tang ${ }^{3}$ \\ Shanchun Guo ${ }^{4}$ \\ 'Department of Physics, Tufts \\ University School of Medicine, Boston, \\ Massachussetts; ${ }^{2}$ Department of \\ Thoracic/Head and Neck Medical \\ Oncology, ${ }^{3}$ Biostatistics, The University \\ of Texas MD Anderson Cancer Center, \\ Houston, Texas; ${ }^{4}$ Sylvester Cancer \\ Center, University of Miami School \\ of Medicine, Florida, USA
}

Correspondence: Mingli Liu

Department of Physics, Tufts

University School of Medicine,

I 36 Harrison Avenue R708, Boston,

MA 02111 , USA

Tel +I 6176362943

Fax +I 6I76360445

Email mingli.liu@tufts.edu
Abstract: To examine whether aberrant DNA methylation in the promoter region might occur earlier in tumorigenesis, particularly in premalignant lesions, we examined biopsies from 111 participants in a chemoprevention trial aimed at reversal of oral leukoplakia, using methylation-specific polymerase chain reaction for the promoter regions of the tumor suppressor gene $C D K N 2 A$ ( $p 16$ ), the putative metastasis suppressor gene for death-associated protein kinase $(D A P-K)$, the DNA repair gene $\mathrm{O}^{6}$-methyguanine-DNA-methyltransferase $(M G M T)$, and the detoxification gene glutathione S-transferase $\mathrm{p} 1(G S T P 1)$. $p 16$ promoter hypermethylation was detected in 21 of $82(25.6 \%), D A P-K$ hypermethylation in 28 of $87(32.2 \%)$, and $M G M T$ hypermethylation in 32 of 106 (30.2\%) oral leukoplakia lesions analyzed. No aberrant methylation was found at the GSTP1 gene in 110 lesions examined. Among 68 biopsies analyzed for all three genes ( $p 16, D A P-K, M G M T), 17$ biopsies were detected with an abnormal methylation pattern at only one gene, 15 at two genes, and 8 at all three genes. Among clinical characteristics and their correlation with methylation, only alcohol consumption was correlated with $D A P-K$ methylation $(P=0.027)$, while $M G M T$ methylation was more frequent in females $(P=0.003)$ and nonsmokers $(P=0.0005)$. A significant correlation was found between $p 16$ and $D A P-K$ hypermethylation; $p 16$ promoter was methylated in 14 (56\%) of 25 lesions with $D A P-K$ methylation, and only $5(11.1 \%)$ of $45 D A P-K$ methylation-negative lesions $(P=0.0001)$. $D A P-K$ aberrant methylation was also significantly correlated with $M G M T$ methylation (16 of 31 in $M G M T$ methylation-positive lesions versus 12 of 52 MGMT methylation-negative lesions, $P=0.0016$ ). Our results suggest that epigenetic mechanisms of inactivation, such as aberrant methylation of p16, DAP-K, and $M G M T$ genes, occur early in head and neck tumorigenesis, and might play a role in the progression of these lesions.

Keywords: $p 16, D A P-K, M G M T, G S T P 1$ genes, methylation, leukoplakia

\section{Introduction}

Methylation of normally unmethylated $\mathrm{CpG}$ islands in gene promoter regions is an increasingly recognized epigenetic mechanism of transcriptional inactivation of tumor suppressor genes or DNA repair genes. ${ }^{1}$ Recent publications have reported that promoter hypermethylation of key genes in critical pathways is common in head and neck squamous cell cancers (HNSCC), as well as in serum and saliva of patients with such cancers. ${ }^{2,3}$ In the present study, to address whether aberrant methylation occurs earlier in carcinogenesis (in premalignant lesions), we analyzed the promoter hypermethylation pattern of the $p 16, D A P-K, M G M T$, and GSTP1 genes using methylationspecific polymerase chain reaction (PCR) in 111 patients who presented with oral leukoplakia. $p 16^{\mathrm{INK} 4 \mathrm{~A}}$ is critical at the G1-S transition of the cell cycle, being responsible for maintaining $\mathrm{Rb}$ protein in its nonphosphorylated state, ${ }^{4}$ and it is frequently 
lost in head and neck cancer through deletion, ${ }^{5}$ promoter hypermethylation, ${ }^{6}$ and rarely by mutations. ${ }^{7} M G M T$ is a DNA repair gene that is frequently inactivated in colon, lung, and brain tumors. ${ }^{8} D A P-K$ is a novel serine/threonine kinase required for interferon gamma-induced apoptotic cell death, and it is frequently methylated in lung cancer. ${ }^{9}$ The detoxification gene GSTP1 encodes a detoxifying enzyme and can be characteristically silenced in prostate, breast, and kidney tumors. ${ }^{10,11}$ GSTP1, in particular, is aberrantly methylated in approximately $90 \%$ of prostate carcinomas, and may be an ideal marker for this tumor type. ${ }^{12}$

\section{Materials and methods Premalignant lesions and head and neck tumor samples}

Baseline biopsies were obtained from patients who participated in a prospective, oral premalignancy chemoprevention trial in the years 1999-1999 at The University of Texas MD Anderson Cancer Center. Paraffin-embedded tissue blocks from biopsy samples at the leukoplakia site from a total of 111 patients were available in the institution's tumor archive. The patient characteristics are presented in Table 1. Tissue sections from 10 patients with HNSCC during the same period were also available for this study. Four to five sections $(4 \mu \mathrm{m})$ from each sample were stained with hematoxylin and eosin. One of these was reviewed by a pathologist for histologic features and the remaining sections were microdissected for methylation analyses. The institutional review boards approved the study to allow us to obtain tissue blocks.

\section{Microdissection and DNA extraction}

The epithelial part of each lesion was microdissected from three to four serial sections of each biopsy, as described previously. ${ }^{13}$ The samples were digested in $100 \mu \mathrm{L}$ of $50 \mathrm{mM}$ Tris- $\mathrm{HCl}$ ( $\mathrm{pH} 8.0$ ), 1\% dodecyl sulfate, and proteinase $\mathrm{K}(0.5 \mathrm{mg} / \mathrm{mL})$ at $42^{\circ} \mathrm{C}$ for $12-24$ hours. Digested products were boiled for eight minutes to inactivate enzymes, and purified using phenol chloroform. DNA was precipitated by the ethanol precipitation method in the presence of glycogen (Boehringer Mannheim Biochemicals, Indianapolis, IN) and resuspended in distilled water.

\section{Methylation-specific polymerase chain reaction}

DNA from oral premalignant lesions and tumor tissues were subjected to bisulfite treatment, as described previously. ${ }^{9}$
Table I Clinical characteristics in I I I subjects with oral premalignant lesions

\begin{tabular}{ll}
\hline Age median years (range) & $56(24-90)$ \\
Gender & 59 \\
Male & 52 \\
Female & 43 \\
Histology & 30 \\
Hyperkeratosis without hyperplasia & 47 \\
Hyperplasia & \\
Dysplasia & 27 \\
Mild & 6 \\
Moderate & 1 \\
Severe & \\
Site & 44 \\
Oral cavity/buccal mucosa & 44 \\
Tongue/floor of mouth & 15 \\
Palate/retromolar trigone & 8 \\
Lip & \\
Smoking status & 21 \\
Never & 49 \\
Former & 40 \\
Current & 1 \\
Missing & \\
Alcohol consumption & 32 \\
Never & 14 \\
Former & 64 \\
Current & 1 \\
Missing &
\end{tabular}

Briefly, 200 ng of DNA was denatured by $\mathrm{NaOH}$ and treated with sodium bisulfite (Sigma Chemical Co., St Louis, MO) by incubation at $55^{\circ} \mathrm{C}$ for $16-18$ hours. DNA samples were then purified using Wizard DNA purification resin (Promega Corp., Madison, WI), treated with $\mathrm{NaOH}$ once more, precipitated by ethanol, and resuspended in distilled water. Bisulfitemodified DNA was amplified by PCR using two primer sets specific for methylated and two primer sets specific for unmethylated sequence of each gene. Primer sequences for the $p 16, D A P-K, M G M T$, and GSTP1 genes were as described previously with minor modifications (Table 2). ${ }^{9,12,14,15}$ Hot start PCR was used. Human placental DNA treated in vitro with SssI methyltransferase (New England Biolabs, Beverly, MA) was used as a positive control for methylated alleles of $p 16, D A P-K, M G M T$, and GSTP1. DNA from normal lymphocytes was used as the control for unmethylated alleles of each gene, and water was substituted for DNA for each set of PCR as the negative control. Each PCR product $(12.5 \mu \mathrm{L})$ was directly loaded onto 3\% agarose gel, electrophoresed, and visualized under ultraviolet illumination after staining with ethidium bromide. PCR was repeated at least twice to ensure reproducibility of results. 
Table 2 Primers for methylation-specific polymerase chain reaction

\begin{tabular}{lllll}
\hline Primer set & Forward primer $\left(\mathbf{5}^{\prime} \rightarrow \mathbf{3}^{\prime}\right)$ & Reverse primer $\left(\mathbf{5}^{\prime} \rightarrow \mathbf{3}^{\prime}\right)$ & $\begin{array}{l}\text { Product size } \\
\text { (base pairs) }\end{array}$ & $\begin{array}{l}\text { Annealing } \\
\text { temperature }\left({ }^{\circ} \mathbf{C}\right)\end{array}$ \\
\hline pI6-M & TTATTAGAGGGTGGGCGGATCGC & GACCCCGAACCGCGACCGTAA & 150 & 64 \\
pI6-U & TTATTAGAGGGTTGGGGTGATTGT & CAACCCCAAACCACAACCATAA & $15 I$ & 60 \\
DAP-M & GGATAGTCGGATCGAGTTAACGTC & CCCTCCCAAACGCCGA & 98 & 56 \\
DAP-U & GGAGGATAGTTGGATTGAGTTAATGTT & CAAATCCCTCCCAAACACCAA & 106 & 61 \\
MGMT-M & GTATGGATTTAGCGTCGGTC & TAAACTCGACGAACGCCG & 110 & 59 \\
MGMT-U & ATGGTATGGATTTTAGTGTTGGTT & ACTATACCTAAACTCAACAAACACC & 130 & 59 \\
GSTPI-M & TTCGGGGTGAGCGGTCGTC & GCCCCAATACTAAATCACGACG & 91 & 57 \\
GSTPI-U & GATGTTTGGGGTTAGTGGTTGTT & CCACCCCAATACTAAATCACAACA & 97 & 57 \\
\hline
\end{tabular}

\section{Results}

\section{Gene promoter hypermethylation profiles in leukoplakia}

Of the 111 biopsy samples, an interpretable methylation pattern for $p 16, D A P-K, M G M T$, and GSTP 1 was obtained in $82,87,106$, and 110 biopsies, respectively. The $p 16$ tumor suppressor gene demonstrated promoter hypermethylation in 21 of $82(25.6 \%)$, the $D A P-K$ gene in 28 of $87(32.2 \%)$, and the MGMT gene in 32 of $106(30.2 \%)$ lesions. No aberrant methylation was found for the GSTP1 gene in 110 leukoplakia lesions analyzed. Representative results are shown in Figures 1-4. For comparison, we also show the methylation status of the above four genes in several head and neck tumor samples, respectively, in Figures 1-4.

\section{Gene promoter hypermethylation and clinicopathologic characteristics}

We examined the correlation of hypermethylation with gender, histology, site, smoking status, and alcohol consumption status, and the data are summarized in Table 3. Females (20 of 48) were more likely to demonstrate $M G M T$ methylation than males ( 12 of $58, P=0.03$, Fisher's exact test), but gender did not affect methylation status for the p16 and DAP-K genes. Methylation status of the three genes was not correlated with histology and site. The frequency of $M G M T$ methylation was significantly higher in never smokers (12 of 19 never, 7 of 48 former, and 12 of 38 current smokers, $P<0.0005$, Fisher's exact test), and a similar trend was seen for individuals who never consumed alcohol (12 of 30 versus 1 of 13 former and 18 of 62 current alcohol drinkers, $P=0.09$, Fisher's exact test). No significant correlation between smoking status and $D A P-K$ methylation was seen. Although $p 16$ methylation was more frequent in current smokers ( 9 of 30 versus 9 of 34 in former and 3 of 18 in never smokers, respectively) the difference was not significant. $p 16$ and $D A P-K$ methylation frequency was also higher, but not significantly so, in current alcohol drinkers (14 of 46 and 21 of 53, respectively, versus 1 of 9 and 0 of 11 former, respectively, and 6 of 27 and 7 of 22 never drinkers).

\section{Association of hypermethylation in $p / 6, D A P-K$, and MGMT}

In this study, methylation status for the $p 16, D A P$ kinase, and MGMT genes was simultaneously determined in 68 biopsy specimens. Forty of $68(58.8 \%)$ had an abnormal methylation pattern in at least one gene. Among them, 17 (25.0\%) had methylation at only one gene, $23(33.8 \%)$ had methylation at two genes, and eight of $68(11.8 \%)$ shared methylation for all three genes examined.

Methylation status was available for both $D A P-K$ and p16, for $D A P-K$ and $M G M T$, and for $p 16$ and $M G M T$ in 70,83 , and 79 matched biopsies, respectively. There was

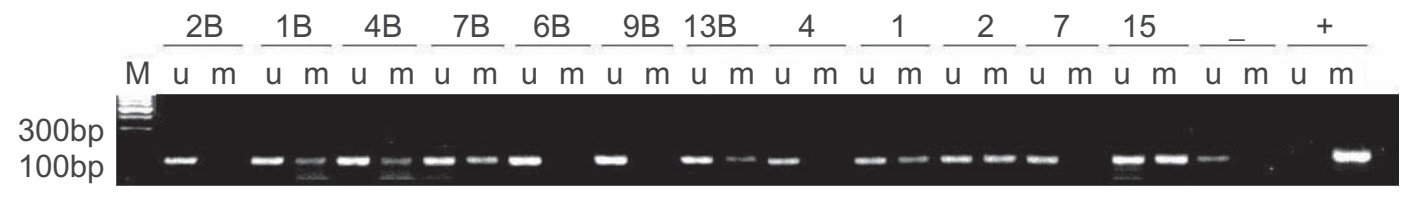

Figure I Examination of methylation of the p/6 gene in seven leukoplakia and six head and neck tumor samples. M (size marker), indicates the polymerase chain reaction product produced by the primer sets specific for the methylated, and $U$ indicates that produced by primer sets specific for the unmethylated. Four leukoplakia samples (IB, 4B, 7B, I3B) show methylation, and three samples (2B, 6B, 9B) are unmethylated. Three head and neck tumor samples (I, 2, I5) show methylation, and two samples (4, 7) are unmethylated. P, Sssl-treated DNA as a positive control; N, peripheral blood DNA as a negative control. 


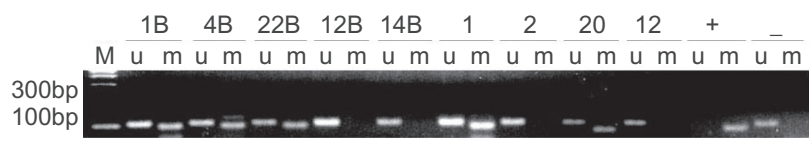

Figure 2 Examination of methylation of the DAP-K gene in five leukoplakia and four head and neck tumor samples. M (size marker) indicates the polymerase chain reaction product produced by the primer sets specific for the methylated, and $U$ indicates that produced by primer sets specific for the unmethylated. Three leukoplakia samples (IB, 4B, 22B) show methylation, and two samples (I2B, I4B) are unmethylated. Two head and neck tumor samples $(I, 20)$ show methylation, and two samples $(2,12)$ are unmethylated. P, Sssl-treated DNA as a positive control; N, peripheral blood DNA as a negative control.

a positive correlation between presence of $p 16$ and $D A P-K$ hypermethylation; $p 16$ hypermethylation was found in $14(56 \%)$ of $25 D A P-K$ methylation-positive lesions and five $(11.1 \%)$ of $45 D A P-K$ methylation-negative lesions $(P=0.0001$, Fisher's exact test). A significant correlation was also found for the concomitant presence of $D A P-K$ and $M G M T$ aberrant methylation. $D A P-K$ methylation was detected in $16(51.6 \%)$ of 31 MGMT methylation-positive lesions and only $12(23.1 \%)$ of 52 MGMT methylationnegative lesions ( $P=0.016$, Fisher's exact test). A trend was seen for correlation of methylation of $p 16$ and $M G M T$ but this did not reach statistical significance; $10(37.0 \%)$ of 27 MGMT methylation-positive lesions showed p16 hypermethylation, compared with 11 (21.2\%) of 52 MGMT methylation-negative lesions.

\section{Discussion}

An increasingly important pathway of transcriptional inactivation for many tumor suppressor and DNA repair genes in $\mathrm{CpG}$ island hypermethylation within the gene promoter region has been reported recently. ${ }^{16}$ It is now generally accepted that promoter hypermethylation plays an important role in the inactivation of tumor suppressor genes in established cancer. Sanchez-Cespedes et $\mathrm{al}^{3}$ and Rosas et $\mathrm{al}^{2}$ have examined large series of head and neck tumors and have found frequent promoter hypermethylation of the tumor suppressor genes $p 16, D A P-K$, and $M G M T$ in tumor

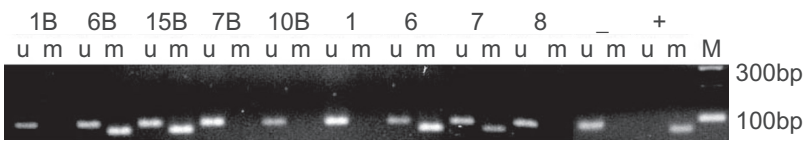

Figure 3 Examination of methylation of the MGMT gene in five leukoplakia and four head and neck tumor samples. M (size marker) indicates the polymerase chain reaction product produced by the primer sets specific for the methylated, and $U$ indicates that produced by primer sets specific for the unmethylated. Two leukoplakia samples (6B, I5B) show methylation, and three samples (IB, 7B, IOB) are unmethylated. Two head and neck tumor samples $(6,7)$ show methylation, and two samples $(I, 8)$ are unmethylated. P, Sssl-treated DNA as a positive control; N, peripheral blood DNA as a negative control.

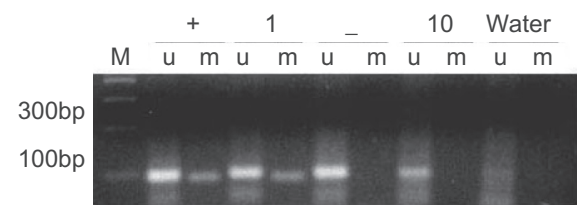

Figure 4 Examination of methylation of the GSTPI gene in two head and neck tumor samples. M (size marker) indicates the polymerase chain reaction product produced by the primer sets specific for the methylated, and $U$ indicates that produced by primer sets specific for the unmethylated. One head and neck tumor sample (I) shows methylation and another sample (10) is unmethylated. P, Sssl-treated DNA as a positive control; $\mathrm{N}$, peripheral blood DNA as a negative control; and water as a negative PCR control.

specimens, and serum and saliva of head and neck cancer patients. Consistent with these reports, several other groups have also investigated the methylation profile of genes $p 16$, $D A P K$, and $M G M T$ in HNSCC (including oral squamous cell carcinoma), which is a promising biomarker for the follow-up and early detection of head and neck cancer recurrence. ${ }^{17-21}$ Steinmann et al showed that methylation of the tumor-related genes was significantly more frequent in squamous cell carcinomas of the head and neck (42\%) compared with normal samples $(23 \%, P<0.05){ }^{22}$ although caution must be exercised using these markers for diagnosis because some of them appear to be age-related. ${ }^{23}$ However, little is known about the epigenetic alteration in premalignant lesions, although recently several reports indicated the correlation between some tumor-related genes, such as $C D K N 2 A / p 16, D A P-K$, and $M G M T$ and premaligancy in endometrial, endobronchial, and cervical lesions. ${ }^{24-26}$ In this study, we investigated the methylation status of $p 16, D A P-K, M G M T$, and GSTP1 genes in leukoplakia patients, in an effort to characterize the timing of these epigenetic alterations during head and neck carcinogenesis.

Our data suggest that multiple epigenetic abnormalities have already occurred in oral premalignant lesions similar to early genetic alterations. ${ }^{27,28}$ We found promoter hypermethylation at $p 16$ in 21 of $82(25.6 \%), D A P-K$ in 28 of 87 (32.2\%), and MGMT in 32 of 106 (30.2\%) of premalignant oral lesions.

Interestingly, there was no difference between the incidence of $p 16, D A P-K$, and $M G M T$ gene methylation in premalignant lesions and those previously reported in HNSCC., ${ }^{2,3}$ Although the frequency of $D A P-K$ hypermethylation was reported as $18 \%$ in the first series of 111 HNSCC patients, ${ }^{3}$ it was $30 \%$ in the second series, ${ }^{2}$ which is very similar to the frequency observed in oral premalignant lesions in our study. These findings indicate that the methylation of these genes occurred very early in the process of head and neck tumorigenesis and possibly additional genetic and epigenetic alterations occurred later to drive the tumorigenesis process. 
Table 3

\begin{tabular}{|c|c|c|c|c|c|c|c|c|c|}
\hline & \multicolumn{2}{|c|}{ p/6 methylation } & \multirow[t]{2}{*}{$P$} & \multicolumn{2}{|c|}{ DAP-K methylation } & \multirow[t]{2}{*}{$P$} & \multicolumn{2}{|c|}{ MGMT methylation } & \multirow[t]{2}{*}{$P$} \\
\hline & Absent & Present & & Absent & Present & & Absent & Present & \\
\hline Gender & & & 0.62 & & & 0.82 & & & 0.03 \\
\hline Male & 31 & 9 & & 32 & 14 & & 46 & 12 & \\
\hline Female & 30 & 12 & & 27 & 14 & & 28 & 20 & \\
\hline Histology & & & 0.27 & & & 0.21 & & & 0.26 \\
\hline Early & 38 & 15 & & 40 & 14 & & 51 & 19 & \\
\hline Dysplasia & 21 & 4 & & 17 & 12 & & 20 & 13 & \\
\hline Smoking & & & 0.62 & & & 0.44 & & & 0.0005 \\
\hline Never & 15 & 3 & & 12 & 7 & & 7 & 12 & \\
\hline Former & 25 & 9 & & 27 & 9 & & 41 & 7 & \\
\hline Current & 21 & 9 & & 19 & 12 & & 26 & 12 & \\
\hline Alcohol & & & 0.47 & & & 0.027 & & & 0.09 \\
\hline Never & 21 & 6 & & 15 & 7 & & 18 & 12 & \\
\hline Former & 8 & 1 & & 11 & 0 & & 12 & 1 & \\
\hline Current & 32 & 14 & & 32 & 21 & & 44 & 18 & \\
\hline Site & & & 0.75 & & & 0.39 & & & 0.44 \\
\hline Oral cavity & 27 & 7 & & 22 & 15 & & 29 & 15 & \\
\hline Tongue & 24 & 10 & & 27 & 10 & & 30 & 14 & \\
\hline Others & 10 & 4 & & 10 & 3 & & 15 & 3 & \\
\hline
\end{tabular}

GSTP1 was not methylated in any of the oral premalignant lesions examined, suggesting that the gene is not an important determinant of head and neck tumorigenesis as opposed to other tumors, such as breast, prostate, and renal cancers. ${ }^{14}$ We found that only one tumor sample showed GSTP1 methylation, as seen in Figure 4. It appears that GSTP1 methylation would not be a frequent event in head and neck cancer although we are unable to explain the initiation of the methylation. Previous studies have shown that hypermethylation is not limited to a single gene, but affects multiple genes concurrently. The presence of such a hypermethylation phenotype was confirmed in several human neoplasms such as gastric cancers, ${ }^{29}$ pancreatic adenocarcinoma, ${ }^{30}$ and colorectal cancers, ${ }^{31}$ among others. In this study, we also found that the $p 16, D A P-K$, and $M G M T$ genes were simultaneously methylated in some of the precancer lesions. Twenty-three of 68 (33.8\%) methylation-positive premalignant lesions showed epigenetic changes at more than one gene, and eight of 68 (11.8\%) were methylated for all the three genes examined simultaneously, thereby implying a general deregulation of $\mathrm{CpG}$ island methylation in precancerous lesions, similar to that in cancers. In particular, the $p 16$ gene was inactivated more frequently in oral premalignant lesions exhibiting $D A P-K$ gene hypermethylation than those that did not ( $56 \%$ versus $11.1 \%$ ); the difference was significant. The $M G M T$ gene was inactivated more frequently in oral premalignant lesions harboring $M G M T$ gene hypermethylation than those that did not (51.6\% versus $23.1 \%)$; this difference was also significant.
The fact that several genes are frequently methylated in oral premalignant lesions implies that the mechanism that normally protects GpG islands from methylation is defective in premalignant cells.

It is unclear whether the positive correlation between p16 and DAP-K methylation and MGMT and DAP-K methylation has any biologic significance, but it is possible that these alterations contribute through different pathways and mechanisms to the tumorigenesis process. $D A P-K$ is $\mathrm{a} \mathrm{Ca}^{2+}$ calmodulin-dependent serine/threonine kinase gene that contains ankyrin repeats and a death domain. It was recently found to display strong tumor suppressive activities, coupling control of apoptosis with metaststasis. ${ }^{32,33} p 16^{\text {INK4a }}$ is an inhibitor of cyclin-dependent kinase CDK4 and CDK6 and regulates the cell cycle negatively. Methylation of p1 $6^{\mathrm{INK} 4 \mathrm{a} 34,35}$ in cancer and premalignancy and $D A P-K$ at least in cancers ${ }^{3,9,12}$ are now recognized as widespread epigenetic alterations in a variety of human cancers.

One interesting observation in our study is that $M G M T$ promoter methylation is observed more frequently in lesions from nonsmokers. MGMT is a DNA repair protein that remove alkyl adducts from the $\mathrm{O}^{6}$ position of guanine, thereby protecting cells against lethal crosslinks caused by alkylating agents and their carcinogenic and cytotoxic effects. ${ }^{36}$ The level of $M G M T$ varies widely according to tumor type and among tumors of the same type. Although changes in $M G M T$ expression are incompletely understood, $p 53$ at physiologic and supraphysiologic levels has been previously found to curtail MGMT transcription. ${ }^{37,38}$ 
Inactivation of $M G M T$ by promoter hypermethylation is associated with $\mathrm{G}$ to $\mathrm{A}$ transition mutations in $\mathrm{K}$-ras and $\mathrm{G}: \mathrm{C}$ to $\mathrm{A}: \mathrm{T}$ transition mutations in $p 53 .{ }^{39,40}$ Interestingly, a smoking-related increase in $M G M T$ expression has been described in human lung carcinomas. ${ }^{41}$ The study of genetic and epigenetic alterations leading to cancer development in nonsmokers is of major interest, and the finding of $M G M T$ hypermethylation in nonsmokers possibly provides a different mechanism of genetic instability through promotion of $p 53$ transitional mutations, as opposed to the usual smoking-related transversions, ${ }^{42}$ and through targeting of other genes, such as $K$-ras. It is even possible that $M G M T$ promoter methylation confers a special mutation phenotype characterized by numerous transition mutations affecting important genes. Further study of MGMT hypermethylation in the subset of nonsmokers is clearly warranted.

Aberrant methylation in oral premalignant lesions was frequently detected in our study, but whether such epigenetic abnormalities are useful adjuncts to histopathologic evaluation of oral mucosal lesions for prediction of risk of malignant transformation remains to be determined through long-term follow-up of the population in this study.

\section{Disclosure}

The authors have no conflicts of interest to report in this work.

\section{References}

1. Baylin SB, Herman JG. DNA hypermethylation in tumorigenesis: Epigenetics joins genetics. Trends Genet. 2000;16(4):168-174.

2. Rosas SL, Koch W, da Costa Cavalho MG, et al. Promoter hypermethylation patterns of $\mathrm{p} 16$, O6-methylguanine-DNA-methyltransferase, and death-associated protein kinase in tumors and saliva of head and neck cancer patients. Cancer Res. 2001;61(3):939-942.

3. Sanchez-Cespedes M, Esteller M, Wu L, et al. Gene promoter hypermethylation in tumors and serum of head and neck cancer patients. Cancer Res. 2000;60(4):892-895.

4. Sherr CJ. Cancer cell cycles. Science. 1996;274(5293):1672-1677.

5. Cairns P, Polascik TJ, Eby Y, et al. Frequency of homozygous deletion at p16/CDKN2 in primary human tumours. Nat Genet. 1995;11(2): $210-212$.

6. Herman JG, Merlo A, Mao L, et al. Inactivation of the CDKN2/p16/ MTS1 gene is frequently associated with aberrant DNA methylation in all common human cancers. Cancer Res. 1995;55(20):4525-4530.

7. Cairns P, Mao L, Merlo A, et al. Rates of p16 (MTS1) mutations in primary tumors with 9p loss. Science. 1994;265(5170):415-417.

8. Esteller M, Hamilton SR, Burger PC, Baylin SB, Herman JG. Inactivation of the DNA repair gene O6-methylguanine-DNA methyltransferase by promoter hypermethylation is a common event in primary human neoplasia. Cancer Res. 1999;59(4):793-797.

9. Tang X, Khuri FR, Lee JJ, et al. Hypermethylation of the deathassociated protein (DAP) kinase promoter and aggressiveness in stage I non-small-cell lung cancer. J Natl Cancer Inst. 2000;92(18): $1511-1516$

10. Esteller M. Aberrant DNA methylation as a cancer-inducing mechanism. Annu Rev Pharmacol Toxicol. 2005;45:629-656.
11. Meiers I, Shanks JH, Bostwick DG. Glutathione S-transferase pi (GSTP1) hypermethylation in prostate cancer: Review 2007. Pathology. 2007;39(3):299-304.

12. Esteller M, Sanchez-Cespedes M, Rosell R, Sidransky D, Baylin SB, Herman JG. Detection of aberrant promoter hypermethylation of tumor suppressor genes in serum DNA from non-small cell lung cancer patients. Cancer Res. 1999;59(1):67-70.

13. Papadimitrakopoulou V, Izzo J, Lippmann SM, et al. Frequent inactivation of p16INK4a in oral premalignant lesions. Oncogene. 1997;14(15):1799-1803.

14. Esteller M, Corn PG, Urena JM, Gabrielson E, Baylin SB, Herman JG. Inactivation of glutathione S-transferase P1 gene by promoter hypermethylation in human neoplasia. Cancer Res. 1998;58(20):4515-4518.

15. Katzenellenbogen RA, Baylin SB, Herman JG. Hypermethylation of the DAP-kinase $\mathrm{CpG}$ island is a common alteration in B-cell malignancies. Blood. 1999;93(12):4347-4353.

16. Baylin SB, Herman JG. Promoter hypermethylation - can this change alone ever designate true tumor suppressor gene function? J Natl Cancer Inst. 2001;93(9):664-665.

17. Calmon MF, Colombo J, Cavalho F, et al. Methylation profile of genes CDKN2A (p14 and p16), DAPK1, CDH1, and ADAM23 in head and neck cancer. Cancer Genet Cytogenet. 2007;173(1):31-37.

18. Ishida E, Nakamura M, Ikuta M, et al. Promotor hypermethylation of p14ARF is a key alteration for progression of oral squamous cell carcinoma. Oral Oncol. 2005;41(6):614-622.

19. Kato K, Hara A, Kuno T, et al. Aberrant promoter hypermethylation of p16 and MGMT genes in oral squamous cell carcinomas and the surrounding normal mucosa. J Cancer Res Clin Oncol. 2006;132(11): 735-743.

20. Martone T, Gillio-Tos A, De Marco L, et al. Association between hypermethylated tumor and paired surgical margins in head and neck squamous cell carcinomas. Clin Cancer Res. 2007;13(17):5089-5094.

21. Righini CA, de Fraipont F, Timsit JF, et al. Tumor-specific methylation in saliva: A promising biomarker for early detection of head and neck cancer recurrence. Clin Cancer Res. 2007;13(4):1179-1185.

22. Steinmann K, Sandner A, Schagdarsurengin U, Dammann RH. Frequent promoter hypermethylation of tumor-related genes in head and neck squamous cell carcinoma. Oncol Rep. 2009;22(6):1519-1526.

23. Attaleb M, El Hamadani W, Khyatti M, et al. Status of p16(INK4a) and E-cadherin gene promoter methylation in Moroccan patients with cervical carcinoma. Oncol Res. 2009;18(4):185-192.

24. Guida M, Sanguedolce F, Bufo P, et al. Aberrant DNA hypermethylation of hMLH-1 and CDKN2A/p16 genes in benign, premalignant and malignant endometrial lesions. Eur J Gynaecol Oncol. 2009;30(3):267-270.

25. Iliopoulos D, Oikonomou P, Messinis I, Tsezou A. Correlation of promoter hypermethylation in hTERT, DAPK and MGMT genes with cervical oncogenesis progression. Oncol Rep. 2009;22(1):199-204.

26. Breuer RH, Snijders PJ, Sutedja GT, et al. Expression of the p16(INK4a) gene product, methylation of the p16(INK4a) promoter region and expression of the polycomb-group gene BMI-1 in squamous cell lung carcinoma and premalignant endobronchial lesions. Lung Cancer. 2005; 48(3):299-306.

27. Mao L, Lee JS, Fan YH, et al. Frequent microsatellite alterations at chromosomes 9p21 and 3p14 in oral premalignant lesions and their value in cancer risk assessment. Nat Med. 1996;2(6):682-685.

28. Rosin MP, Cheng X, Poh C, et al. Use of allelic loss to predict malignant risk for low-grade oral epithelial dysplasia. Clin Cancer Res. 2000;6(2): 357-362.

29. Toyota M, Ahuja N, Suzuki H, et al. Aberrant methylation in gastric cancer associated with the $\mathrm{CpG}$ island methylator phenotype. Cancer Res. 1999;59(21):5438-5442.

30. Ueki T, Toyota M, Sohn T, et al. Hypermethylation of multiple genes in pancreatic adenocarcinoma. Cancer Res. 2000;60(7):1835-1839.

31. Toyota M, Ahuja N, Ohe-Toyota M, Herman JG, Baylin SB, Issa JP. $\mathrm{CpG}$ island methylator phenotype in colorectal cancer. Proc Natl Acad Sci U S A. 1999;96(15):8681-8686. 
32. Cohen O, Inbal B, Kissil JL, et al. DAP-kinase participates in TNF-alpha- and Fas-induced apoptosis and its function requires the death domain. J Cell Biol. 1999;146(1):141-148.

33. Levy-Strumpf N, Kimchi A. Death associated proteins (DAPs): From gene identification to the analysis of their apoptotic and tumor suppressive functions. Oncogene. 1998;17(25):3331-3340.

34. Merlo A, Herman JG, Mao L, et al. 5' CpG island methylation is associated with transcriptional silencing of the tumour suppressor p16/CDKN2/MTS1 in human cancers. Nat Med. 1995;1(7) 686-692.

35. Nuovo GJ, Plaia TW, Belinsky SA, Baylin SB, Herman JG. In situ detection of the hypermethylation-induced inactivation of the p16 gene as an early event in oncogenesis. Proc Natl Acad Sci U S A. 1999; 96(22):12754-12759.

36. Pegg AE, Dolan ME, Moschel RC. Structure, function, and inhibition of O6-alkylguanine-DNA alkyltransferase. Prog Nucleic Acid Res Mol Biol. 1995;51:167-223.

37. Grombacher T, Eichhorn U, Kaina B. p53 is involved in regulation of the DNA repair gene O6-methylguanine-DNA methyltransferase (MGMT) by DNA damaging agents. Oncogene. 1998;17(7):845-851.
38. Srivenugopal KS, Shou J, Mullapudi SR, Lang FF Jr, Rao JS, Ali-Osman F. Enforced expression of wild-type p53 curtails the transcription of the $\mathrm{O}(6)$-methylguanine-DNA methyltransferase gene in human tumor cells and enhances their sensitivity to alkylating agents. Clin Cancer Res. 2001;7(5):1398-1409.

39. Esteller M, Risques RA, Toyota M, et al. Promoter hypermethylation of the DNA repair gene $\mathrm{O}(6)$-methylguanine-DNA methyltransferase is associated with the presence of $\mathrm{G}: \mathrm{C}$ to $\mathrm{A}: \mathrm{T}$ transition mutations in p53 in human colorectal tumorigenesis. Cancer Res. 2001;61(12) 4689-4692.

40. Esteller M, Toyota M, Sanchez-Cespedes M, et al. Inactivation of the DNA repair gene O6-methylguanine-DNA methyltransferase by promoter hypermethylation is associated with $\mathrm{G}$ to $\mathrm{A}$ mutations in K-ras in colorectal tumorigenesis. Cancer Res. 2000;60(9):2368-2371.

41. Mattern J, Koomagi R, Volm M. Smoking-related increase of O6-methylguanine-DNA methyltransferase expression in human lung carcinomas. Carcinogenesis. 1998;19(7):1247-1250.

42. Greenblatt MS, Bennett WP, Hollstein M, Harris CC. Mutations in the p53 tumor suppressor gene: Clues to cancer etiology and molecular pathogenesis. Cancer Res. 1994;54(18):4855-4878.
Pathology and Laboratory Medicine International

\section{Publish your work in this journal}

Pathology and Laboratory Medicine International is a peer-reviewed, open access journal focusing on innovative basic research and translational research related to pathology or human disease. The journal includes original research, updates, case reports, reviews and commentaries on current controversies. The Academic Sponsor

\section{Dovepress}

of this journal is the Chinese American Pathology Association (CAPA). The manuscript management system is completely online and includes a very quick and fair peer-review system. Visit http://www.dovepress.com/testimonials.php to read real quotes from published authors.

Submit your manuscript here: http://www.dovepress.com/pathology-and-laboratory-medicine-international-journal 